IRA-International Journal of Education \& Multidisciplinary Studies

ISSN 2455-2526; Vol.15, Issue 05 (Oct.-Dec. 2019)

Pg. no. 175-180.

Institute of Research Advances

http://research-advances.org/index.php/IJEMS
QUARTERLY

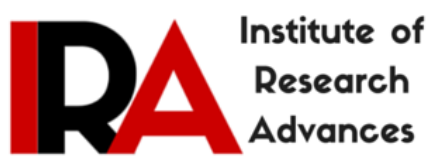

\title{
An Aesthetic Study of Rhetorical Devices in David Hawkes's Version of Chu Ci（楚辞）
}

Lifen Gao

School of Foreign Studies, Yangtze University, Hubei, 434023 PRC China.

Type of Work: Peer-Reviewed

DOl: http://dx.doi.org/10.21013/jems.v15.n5.p3

\section{How to cite this paper:}

Gao, L. (2019). An Aesthetic Study of Rhetorical Devices in David Hawkes's Version of Chu Ci (楚辞). IRA International Journal of Education and Multidisciplinary Studies (ISSN 2455-2526), 15(5), 175-180.doi: http://dx.doi.org/10.21013/jems.v15.n5.p3

(C) Institute of Research Advances.

This work is licensed under a Creative Commons Attribution-Non Commercial 4.0 International License subject to a proper citation to the publication source of the work.

Disclaimer: The scholarly papers as reviewed and published by the Institute of Research Advances (IRA) are the views and opinions of their respective authors and are not the views or opinions of the IRA. The IRA disclaims of any harm or loss caused due to the published content to any party.

Institute of Research Advances is an institutional publisher member of Publishers International Linking Association Inc. (PILA-CrossRef), USA. The institute is an institutional signatory to the Budapest Open Access Initiative, Hungary advocating the open-access of scientific and scholarly knowledge. The Institute is a registered content provider under Open Access Initiative Protocol for Metadata Harvesting (OAI-PMH).

The journal is indexed \& included in WorldCat Discovery Service (USA), CrossRef Metadata Search (USA), WorldCat (USA), OCLC (USA), Open J-Gate (India), EZB (Germany) Scilit (Switzerland), Airiti (China), Bielefeld Academic Search Engine (BASE) of Bielefeld University, Germany, PKP Index of Simon Fraser University, Canada.

This paper is one of the phased results of the "Research on Chu Ci Translation and Image Construction of Ancient China" of the project of the Humanities and Social Sciences in Hubei Province. 


\begin{abstract}
Chu Ci(楚辞)is one of the origins of Chinese romantic literature. There are many English versions since the late 19th century, among which David Hawkes's version is of great popularity in the west. His translation conveys both academic and literary value with a great sense of beauty. In his translation, Davis Hawkes uses various translation artistic techniques and methods to achieve the finest effect, for example, successful presentation of the rhythm and structure of $\mathrm{Chu} \mathrm{Ci}$ and appropriate use of rhetorical devices such as alliteration, antithesis, parallelism and reduplication. This study tries to study the rhetorical devices in Hawkes's version from the perspective of translation aesthetics so that the readers can appreciate the beauty of Chi Ci better.
\end{abstract}

Keywords: $\mathrm{Chu} C i$; translation methods; rhetorical devices; aesthetic study

\title{
1. Introduction
}

As a poetry anthology of romanticism in China, $C h u C i$ is one of the most classic work in the history of Chinese literary and draws the attention of readers both at home and abroad. There are various English versions by different scholars. David Hawkes's Ch'u Tz'u - The Song of the South (1962) plays a leading role in the spread of $\mathrm{Chi} C \mathrm{C}$ in western countries as the first version that covers all the volumes. However, the situation is that few studies are conducted on the rhetorical devices in Hawkes's version from the perspective of translation aesthetics. This study will mainly discuss how the beauty of $C h i C i$ is embodied and what rhetorical devices are used in Hawkes's version in light of the translation aesthetics theory. It categorizes translation into art and emphasizes the significance of "producing an accessible and aesthetically satisfying vernacular style" (Bassnett, 2002:56). It is of great help in the appreciation of Chi Ci's beauty.

\section{Aesthetic Features of $\mathrm{Chu} \mathrm{Ci}$}

Aesthetic features of $\mathrm{Chu} C i$ are embodied both in its forms and in its spirit. Like most ancient Chinese poems, rhyme frequently appears in Chuci through the use of the Chinese character “Xi (兮)”. “Xi (兮)” can be placed in two different positions, the first in the middle of the line (“萬肴蒸兮兰藉, 煘桂酒兮椒 浆” from Nine Songs(九歌) ) and the other at the end of a double line (“亦余心之所善兮” from Li Sao

(离骚) ). Two kinds of "Xi" can reduce the tempo of the line or poem in spite of the different positions, showing a musical beauty. Such form is a new creation of Chinese ancient poetry then. Chu Ci is free on the number of Chinese character in each line (e.g. “势鸟之不群兮, 自前世而固然” from Li Sao) after getting rid of the form in which one line is composed of four Chinese characters in Shi Jing（诗经）. The new form, which is called Sao Style, can break the limitation of ancient poems and is effective in expressing the sentiment of the author as well. Rhyme is not the only means since there are rich reduplications used in Chu Ci such as “穆眇眇之无垠兮，莽芒芒之无仪”in Nine Chapters(九章）. Various images in $C h u C i$ also indicates the aesthetic values of it. A wonderful world is constructed through the image of sweet plants, animals, historical images, geographical images and mythological images. Image of sweet plants enjoys the highest frequency with the appearance for about 235 times in Chu Ci (Cao Dachong, 1991:186). Image of animals including animals both in the real world and the fairy world can be put into two types, namely, those stand for people with loyalty and nobility such as horse and phoenix and those for villains, like swallows in Jiu Zhang. Other images include great 
historical and legendary figures and objects as well. All of them contain rich cultural connotations.

Aesthetic values can also be embodied in the description of scenery and sentiment in $\mathrm{Chu} C i$ through the wide use of reduplication and onomatopoeia. The reduplication of “曼曼”, “炏㷋”, and “翼翼” can vividly describe the action of animals and scenery. The natural scenery description “虽萎绝其亦何伤 兮, 哀众芳之芜秽” can express the sadness of the poet well. Sentiment in Chu Ci can be categorized into three types. The first is to show Qu Yuan(屈原) 's loyalty to his country (e.g.“长太息以掩涕兮，哀民 生之多艰.” In $\mathrm{Li} \mathrm{Sao}$ ). The second is to show his pursuit of noble quality. Many flowers in $\mathrm{Chu} C \mathrm{Ci}$ symbolize virtues. The use of flowers to sew his cloth and to build the house can show his will of being a nobleman. The third is to show his great anger to the corruption of the world. In Li Sao, the poet depicted his sorrow by expressing his emotion directly. A sentence like “曾㱆刹余郁邑兮, 衰朕时之不当” is a mournful sigh for his being persecuted.Sao Style contains a beauty both in rhythm and structure with an irreplaceable form and it is worthwhile to discuss and study the aesthetic value in its English version.

\section{Rhetorical devices in Hawkes's version of $\mathrm{Chu} \mathrm{Ci}$}

As typical characteristics of the traditional Chinese poetry, rhythm and end rhymes are frequently applied in $\mathrm{Chu} C \mathrm{C}$. Hawkes adopted various kinds of rhetorical devices in order to rebuild the beauty especially the beauty of sound and structure.

Sound is the carrier of aesthetics and artistic concept. Beauty of music can be felt when $C h u C i$ is read aloud. To rebuild the poetic beauty of $\mathrm{Chu} C \mathrm{Ci}$, most translators try to adopt rhythm and rhyme especially end rhyme in their translation since the Chinese character Xi (兮) carries so high a frequency in the work. Hawkes holds that rhyme should be used flexibly rather strictly in the translation of $\mathrm{Chu} C i$, which can also rebuild the beauty of sound in $\mathrm{Chu} C \mathrm{Ci}$. Different rhetorical devices are applied with examples followed.

\subsection{Alliteration}

As the phonetic rhetoric, alliteration has the function of repeating the first consonant. It is characterized by the combination of language and emotion as well as sound and meaning. The purpose is to enable the poem to be more charming and impressive. Readers can immediately sense the beauty of sound. The following are some examples:

Example 1:

鮗愁悴而委惰分, 老苒苒而逮之。

\section{《哀时命》}

I am sunk in wretchedness and worn with weariness,

And old age draws on and soon will catch up with me.

(Hawkes, 1962:136)

This is a typical alliteration since the three words "worn" "with" "weariness" share the same consonant /w/. And the words connotes Qu Yuan's miserable fate. "With" and "weariness" even share the first vowel /i/. A beauty of rhythm can be easily embodied with the repetition of consonant and vowels. Another repetition in sound is achieved since "wretchedness" and "weariness" share the same suffix. 
Alliteration in Hawkes's version can embody the beauty in the sound but also the poet's mood.

Example 2:
步徙倚而遥思兮, 怊惝怳而乘怀。
意荒忽而流荡兮， 心愁悽而增悲。

\section{《远游》}

Restless I paced, with my mind on distant things;

Despairing, frustrated, consumed with constant yearning.

My thought were wild and wandered distractedly;

My heart was melancholy with mounting sadness.

(Hawkes, 1962:81)

These lines aim to express Qu Yuan's sorrow and frustration. Three pairs of alliteration can be found: "consumed" and "constant" with consonance "/k/", "wild" and "wandered" with consonance "/w/", and "melancholy" and "mounting" with consonance "/m/". "Wild" shows the author's strong desire for freedom and escape from reality, which is consistent with the words "wander" "constant" and "consumed". Sadness and disappointment can be sensed with the use of "melancholy" and "mounting". The three pairs of alliteration are effective in displaying both the beauty of sound and the meaning of $C h u$ $\mathrm{Ci}$. Besides, the first two lines share the same vowel/æ/, which also connotes a beauty of repetition.

\subsection{Reduplication}

As a typical characteristic in Qu Yuan's work, reduplication plays an important role in the embodiment of the beauty of the poem. And it is essential to reproduce the beauty of reduplication in translation. Hawkes adopts repeated adjectives, adverbs and short phrases in the translation of reduplication words in $\mathrm{Chu} C i$, which is effective in achieving equivalence both in the form and in the sound. Here is an example:

Example 3:

怊茫茫而无归兮,

怅远望此旷野。

《哀时命》

Far off, Far off: I shall never more return:

Sadly I gaze in the distance, over this empty plain.

(Hawkes, 1962:139)

The beauty of rhythm can be easily appreciated with the repetition of "far off" in the translation. As readers, we also can easily feel Qu Yuan's sadness, sorrow and desolation since he is so aimless and has no sense of belonging. Hawkes is so wise to use the word "far off" because it can indicate that the poet is both far away from his homeland and far away from his dream.

\section{Antithesis}

Antithesis is a common technique in $C h u C i$ and in much ancient Chinese poetry as well. Hawkes tries to 
reconstruct the sentence structure and rebuilds the beauty of the original work with the same sentence pattern.

Example 4:

谓骐骥兮安归?

谓凤皇兮安棲?

- 《九辩》

What of the fine steed? where is he to turn?

What of the phoenix? where is he to rest?

(Hawkes, 1962: 95)

Hawkes does not completely follow the form of the original work but wisely divides the two questions into four by using "what of" and "where is" twice. Superficially understanding, it seems that the questions are about steed and phoenix but actually they both stand for the poet himself. Hawkes's vision can vividly show the author's confusion and lostness in the twisty world by using more questions.

\section{Parallelism}

Example 17:

悲哉, 秋之为气也！

萧瑟兮草木摇落而变衰。

憭栗兮若在远行,

登山临水兮送将归。

泬漻兮天高而气清,

寂察兮收潦而水清。

慨悽增欷兮, 薄寒之中人,

怆怳懭悢兮, 去故而就新。

坎廪兮贫士失职而志不平,

廓落兮羁旅而无友生,

惆怅兮而私自怜！

- 《九辩》

Alas for the breath of autumn!

Wan and drear! flower and leaf fluttering fall and turn to decay.

Sad and lorn! as when on journey far one climbs a hill and looks down on the water to speed a returning friend.

Empty and vast! the skies are high and the air is cold.

Still and deep! the streams have drunk full and the waters are clear.

Heartsick and sighing sore! for the cold draws on and strikes into a man.

Distraught and disappointed! I leave the old and turn towards the new.

Afflicted! the poor esquire has lost his office and his heart rebels.

Desolate! on his long journey he rests with never a friend.

Melancholy! and secretly pities himself.

(Hawkes, 1962:92)

Fifteen adjectives phrases are adopted in Hawkes's version totally and can be classified into two groups: one for scenery description and the other for emotion depiction. Although Hawkes does not put the 
adjective phrases together in the translation of these lines, a beautiful concept can still be sensed. Cold autumn is portrayed since the sky is so empty and vast and the stream is so still and deep. At the same time, the author's sentiment is reflected through the adjectives and adjective phrases like "sad and lorn", "distraught and disappointed", "afflicted", "desolate" and "melancholy". Hawkes's application parallelism also shoulders double missions: embodiment of form aesthetic and the poet's emotion.

\section{Concluding Remarks}

Form and meaning are like two sides of a coin. A perfect translation means an aesthetic reproduction of the original version both in form and in the soul. However, it is not an easy job. Sometimes the translator has no choice but to sacrifice the form so as to express the meaning. Generally speaking, Hawkes's translation is flexible without following the verses strictly. Sound and sentence structure are widely and wisely used throughout Hawkes's version. Alliteration and reduplication are employed on the aspect of sound. As for structure, antithesis or parallelism are more effective. The limitation is that the present study is not a multi-angle of view since it only analyzes how Hawkes applies rhetorical devices like alliteration, parallelism, reduplication and antithesis. It is significant to discuss more rhetorical devices and even translation methods adopted by Hawkes in future research and based on more theoretical frameworks.

\section{References}

[1]. Hawkes. D. Ch'u Tz'u: The Song of the South - An Ancient Chinese Anthology[M]. Boston: Beacon Press, 1962.

[2]. Bassnett, S. Translation Studies[M]. London: Routledge, 2002.

[3]. Nida, E. A. Toward a Science of Translating [M]. Shanghai Foreign Language Education Press, 2004.

[4]. William, W \& Coleridge, S. T. Lyrical Ballads [M]. London: Routledge, 1991.

[5]. Pan, X. \& Jiang, L. Poetics and Art of the book of songs and Li Sao[M]Shanghai: Shanghai Classics Publishing House, 2004.

[6]. Liu, M. An Introduction to Translation Aesthetics[M].Beijing: China Foreign Translation Publishing Company, 2005.

[7]. Cao, D. Quyuan's Thought and Literature and Art[M].Changsha: Hunan Publishing House, 1991.

[8]. Li, Y. A Brief Analysis of Hawkes's English Translation of Chuci[J].Chinese Translators Journal, 1992(01):40-42. 